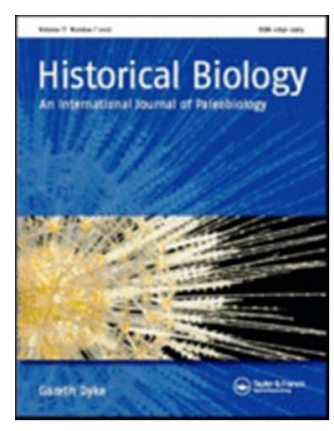

\title{
Teeth, fossil record and evolutionary history of the cowtail stingray Pastinachus Rüppell 1829
}

\begin{tabular}{|r|l|}
\hline Journal: & Historical Biology \\
\hline Manuscript ID & GHBI-2017-0212 \\
\hline Danuscript Type: & Original Article \\
\hline \hline Complete List of Authors: & $\begin{array}{l}\text { Adnet, sylvain; Institut des sciences de l'evolution, Forme } \\
\text { Mouana, Medhi; Institut des sciences de l'evolution, Forme } \\
\text { Charruault, Anne-Lise; Institut des sciences de l'evolution, Forme } \\
\text { Essid, El Mebrouk; Office National des Mines (ONM) } \\
\text { Hayet Khayati Ammar, Hayet ; Office National des Mines (ONM) } \\
\text { Marzougui, Wissem ; Office National des Mines (ONM) } \\
\text { Merzeraud, Gilles; Geosciences Montpellier } \\
\text { Tabuce, Rodolphe; Institut des sciences de l'evolution, Forme } \\
\text { Vianey-Liaud, Monique; Institut des sciences de l'evolution, Forme } \\
\text { Marivaux, Laurent; institut des science de l'évolution }\end{array}$ \\
\hline Keywords: & Hypolophin, fossil record, evolutionary history, new species, Tunisia \\
\hline & \multicolumn{2}{|l}{} \\
\hline
\end{tabular}




\section{Teeth, fossil record and evolutionary history of the cowtail stingray Pastinachus Rüppell 1829}

Sylvain Adnet ${ }^{1 *}$, Medhi Mouana ${ }^{1}$, Anne-Lise Charruault ${ }^{1}$, El Mebrouk Essid $^{2}$, Hayet Khayati Ammar ${ }^{2}$, Wissem Marzougui ${ }^{2}$, Gilles Merzeraud ${ }^{3}$, Rodolphe Tabuce $^{1}$, Monique Vianey-Liaud ${ }^{1}$ and Laurent Marivaux ${ }^{1}$

${ }^{1}$ Laboratoire de Paléontologie, Institut des Sciences de l'Évolution de Montpellier (ISE-M, UMR 5554, CNRS/UM/IRD/EPHE), c.c. 064, Université de Montpellier, place Eugène Bataillon, F-34095 Montpellier Cedex 05, France

${ }^{2}$ Office National des Mines (ONM), 24 rue 8601, 2035 La Charguia, Tunis BP : 215, 1080 Tunis, Tunisia

${ }^{3}$ Géosciences Montpellier (UMR-CNRS 5243), c.c. 060, Université de Montpellier, Place Eugène Bataillon, F-34095 Montpellier Cedex 05, France

Corresponding author: sylvain.adnet@umontpellier.fr 


\section{Teeth, fossil record and evolutionary history of the cowtail stingray Pastinachus Rüppell 1829}

Hypolophin 'dasyatids' are a common group of large stingrays today frequenting the Indo-Pacific inshores. Being often harvested in their restricted area, few are known about their biology and their evolutionary history despite a very peculiar dental pattern making it easy to track their fossil record. An abundant material consisting of isolated teeth from Late Bartonian (38-40 Ma) lagoonal deposits of Djebel el Kébar, Tunisia, allows to describe a new stingray, Pastinachus kebarensis nov. sp. This taxon represents the oldest occurrence for this genus but also the oldest fossil record for hypolophins. A dental comparison of these fossils with 3D rendered models of fresh specimens testifies that early hypolophin representatives had already a strongly arcuate and bulbous upper jaw, interlocking with a broad and elongated tooth plate on the lower jaw. This new fossil and its fossil relatives (here updated), indicate a pre-Bartonian origination for hypolophins in western Neotethys, and reveal a rapid and widespread colonization of the proto-Mediterranean Sea, western Atlantic and Indo-Pacific coasts during the late Paleogene-early Neogene. Finally, it is worth noting that early hypolophin representatives seemingly entered freshwater habitats occasionally as modern cowtail stingrays do.

Keywords: Hypolophin, fossil record, new species, Tunisia, evolutionary history.

\section{INTRODUCTION}

The Dasyatidae (Jordan 1888) is a large stingray family represented by 19 genera and at least 86 living species (Last et al. 2016a-c). Excluding the pelagic stingray Pteroplatytrygon violacea (Bonaparte 1832), most are marine, demersal, living inshore on continental and insular shelves (rarely found deeper than $400 \mathrm{~m}$ ). Some stingrays can live in freshwater, occurring in rivers more than $240 \mathrm{~km}$ from the coast (Last et al. 2016). Among it, Hypolophinae (Stromer 1910), and its junior synonym Pastinachinae (Roberts 2006) is a subfamily including six Indo-Pacific stingrays belonging to 
Makararaja Roberts 2006 and Pastinachus Rüppell 1829 (posteriorly named Hypolophus by Müller and Henle 1837). Anatomically, both are partly characterized among Dasyatidae by their strongly arcuate and bulbous upper jaw interlocking with a broad and elongated tooth plate on the lower jaw (Last et al. 2005, 2010a-b, 2016a-c ; Roberts 2006). Teeth are grinding type, quincuncial and hexagonal or rhomboid, varying in size and shape depending the files. Other anatomical features corroborate this clade as a caudal sting inserted posteriorly on tail, supporting a well-developed ventral skin fold (cowtail). The genus Makararaja differs in having a nearly round disc, very fine dermal denticles and four oral papillae, contrary to Pastinachus, in which the disc is rhombic, with a well-developed denticle band including pearl-shaped midscapular thorns, and five oral papillae (Roberts 2006).

Compared to the unique freshwater Makararaja chindwinensis Roberts 2006, which has been described from only one specimen collected in the Chindwin River, Irrawaddy basin, in northern Myanmar (Roberts 2006), Pastinachus was thought to consist of a single species widely distributed around the Indo-Pacific coasts: P. sephen Forsskål 1775. However, recent advances in molecular phylogenies have demonstrated that this species includes today at least five amphidromous species: $P$. ater Macleay 1883, P. gracilicaudus Last and Manjaji-Matsumoto 2010, P. sephen, P. solocirostris Last et al. 2005, and P. stellurostris Last et al. 2010. Most of them live on marine soft substrates of Indo-Malay Archipelago, except for $P$. sephen which is exclusively restricted from Red Sea to Pakistan area. Pastinachus ater is the largest and the most widespread species, inhabiting all the Indo-Pacific inshores, from Madagascar to North Australia coasts, and also occurring in estuaries and freshwater (Last et al. 2016c) up to several hundreds of kilometres in the Ganges River (Chaudhuri 1911). If observed specimens of Pastinachus are known to belong to a solitary foraging species that 
occasionally groups when resting on shallow sand flats (Semeniuk and Dill 2006), and that feeds on small fishes, molluscs, crustaceans and marine worms (Randal and Hoover 1995), the biology of the subfamily members is still poorly understood.

\section{TOOTH MORPHOLOGY AND FOSSIL RECORD}

Despite its unique dental pattern among dasyatids (Last et al. 2016a,c), teeth morphology along jaws of Pastinachus have long remained elusive. Only some teeth of Pastinachus have been figured by Herman et al. (1998, plates 10-13) and Cappetta (2012, fig. 15 and 413). Recently, we had the opportunity to scan the fresh specimen of Pastinachus ?ater, a male of $75 \mathrm{~cm}$ DW from Java, available in our collections (UM REC 818M) and partially figured in Cappetta (2012, fig. 15). The jaws of this specimen was subject to a X-ray micro-CT scans (using a SkyScan 1076 Brucker CT scanner, MRI, ISE-M facilities) in order to obtain 3D digital models of the upper and lower jaws. We extracted the digital surface using the segmentation tools of AVIZO 6.3 (Visualization Sciences Group) and compiled in 3D rendered models. The segmentation process was performed slice-by-slice manually and we segmented the tooth plates and cartilaginous jaws in two separate label fields (Fig. 1A-F). Indeed, the anatomy of tooth plates is now available with regard to dental variations along both jaws.

The dentition of hypolophins is characteristic of the crushing-grinding type, described in batoids (see Cappetta 2012 and references herein). There is a well-marked monognathic heterodonty consisting in the presence of teeth exhibiting a grinding type, and to a lesser extent in the presence of tooth files characterized by a crushing type (e.g., anterior upper teeth). Dignathic heterodonty is marked by the grinding complex between teeth of pestles (curved upper lateral teeth) and teeth of crucibles (anterolateral lower teeth). In hypolophins, this mixing between crushing and grinding types is 
particularly notable on upper jaw (Fig. 1A-C), the lower jaw exhibiting a tooth plate more uniform (Fig.1C), as in most batoids. Indeed, each half-upper jaw consists of a strongly convex dental plate made of large hexagonal teeth, which are narrowly imbricated (Fig. 1C). The contact between the right and left dental plates in the symphyseal region is made by 5-6 tooth files (see Fig. 1C for nomenclature) of crushing type, located in a deep labio-lingual depression. Jaw cartilages have a strongly undulate profile (Fig.1A) and the shape of teeth varies as a result, with both the position relative to high and low points along the jaw and distance between the symphysis and proximal jaw extremities (Underwood et al. 2015). Consequently, the morphological changes in tooth design are gradual along the half-jaw between the lozenge shaped crushing teeth of the labio-lingual depression (symphyseal and anterior tooth files; see Fig. 1C for nomenclature) and the hexagonal elongated grinding teeth of the convex plate (6-7 lateral tooth files). The commissural edges of tooth plate are abruptly limited by teeth with pentagonal occlusal face (posterior tooth file). The lower dentition is rather flat (Fig. 1C-D) on the whole with lozenge shaped (or slightly hexagonal in more anterior tooth files) to pentagonal (posterior tooth file) crushing-grinding teeth. Dental pattern along both jaws seems quite homogenous within the subfamily if we consider the rare jaw illustrated for identified species (Roberts 2006: for Makararaja chindwinensis; Last and Manjaji-Matsumoto 2010, fig. 3 for P. gracilicaudus; Last et al. 2010, fig. 3 for $P$. solocirostris; and Last et al. 2010, fig. 5 for P. stellurostris, respectively). In addition, sexual heterodonty seems absent according Herman et al. (1998) but the latter observations are based on old systematics (see Introduction), considering that specimens of males and females might not be conspecific and thus, represent distinct species. Herman et al. (1998, p. 154) and Cappetta (2012, p. 420-421) have figured several isolated teeth of lower and upper hypolophin jaws, and have extensively 
described the tooth morphology of Pastinachus, even if we provisionally exclude a dubious specimen from Sarawak figured by Herman et al. (1998, fig. 13, as

"Pastinachus sephen"). Indeed, this specimen displays teeth inconsistent in morphology to the hypolophin dental pattern (e.g., polyholacorhize root, occlusal surface of crown rounded and smooth, lack of posterior bulge on labial face (under the labial visor) in lateral teeth, high root compared to the fine crown). As in many dasyatids and especially in those where the crushing-grinding pattern is most efficient, the enameloid coat and the outer layer of orthodontine are very thin and rapidly removed by wear, the remaining root consisting of trabecular dentine (osteodont type). Most of the vascularization canals are vertically directed with some interconnections (Fig. 1H). However, when not yet functional (teeth renewal before moving forwarding), the entire occlusal surface of teeth bears an irregular, pitted enameloid. Even if these ornamentations are widely smoothed on the 3D surface rendering, they are visible on most of the tooth files located in the back of the mouth, before functional occlusion, between upper and lower jaws. The crown of teeth is only slightly elevated compared to the root, except in teeth that are subjected to less grinding stresses, as in symphyseal and anterior upper tooth files (Fig. 1 A-C). Root is at the holaulacorhize stage (Herman et al. 1998; Cappetta 2012), with a complete opening of the vascular canal, converted to a unique groove with a foramen opening in the middle in all teeth of both jaws (Fig. 1 EG). Inner and outer foramina are absent. The two root lobes are generally displaced towards the back and mostly symmetrical to slightly asymmetrical in lateral and posterior tooth files, especially along the upper jaw (Fig. 1E-F). Sometimes, abnormal teeth display more than two lobes (Fig. 1F).

Because of a lack of information regarding Pastinachus' tooth morphology before recent illustrated works, fossils of rays belonging to this genus were long 
described as belonging to Dasyatis. Conversely, and for the same reason, some teeth originally described as Pastinachus (formerly Hypolophus) were considered as belonging to another genus. The oldest documented occurrences of Pastinachus are from the Priabonian (Late Eocene, Paleogene) of North Africa. Firstly attributed to Dasyatis spp., the genus Pastinachus occurs in the southwestern Morocco (Adnet et al. 2010). Teeth of Pastinachus were collected subsequently in several localities of Egypt, notably in the Qasr el-Sagha and Birket Qarun formations, Fayum (Murray et al. 2010, fig. 2, C-D; Underwood et al. 2011, fig.5. DD-FF ; Antar 2011, fig. 30.J), and in Km55, Bahariya Oasis (Adnet et al. 2011, fig. 4. F-H). Murray et al. (2010) noticed few differences between teeth they figured from Late Eocene Birket Qarun Formation and Hypolophus sylvestris (White 1931), an early Eocene species based on teeth and thorns from Abbey Wood, Beckenham, High Halstow, and Upnor, England (White 1931, p.7073) and attributed posteriorly by Cappetta (1980) to the extinct genus Hypolophodon, a large early Paleogene dasyatid exhibiting a grinding-type dentition (Cappetta 2012). However, given the tooth shape (hexagonal crown with a bilobed root) and the presence of imbricated teeth with a posterior bulge on the labial face of crown, it is highly probable that the teeth from the Birket Qarun Formation belong to Pastinachus and not to Hypolophodon. In the Neogene, some teeth were reported from the Maradah Formation, Early Miocene of Jabal Zaltan, Libya (Argyriou et al. 2015) and identified as Pastinachus. Sahni \& Mehrotra (1981, pl. 3, 5-6, no 7) and more recently Sharma \& Patnaik (2013, fig. 6. A-D) have figured teeth from the Lower Miocene Baripada Beds (Odisha, India) that they assigned to Dasyatis sylvestris White 1931. However, the tooth morphology strongly reminds those of found in the Late Paleogene, and as such must be considered as fossil representatives of Pastinachus. A tooth (Dartevelle and Casier 1959, pl. XXXIV, 11a-d) and a dermal buckle (Dartevelle and Casier 1959: pl. XXXVI, 
9a, b) from the Miocene of Malembe (Cabinda, Angola) have also been attributed to Hypolophus malembeensis Dartevelle and Casier 1959. Dated in fact to the early Oligocene by the associated mammals (Pickford 1986), Cappetta (2006) assigned this species to the genus Hypolophodon despite it represented an unexpected occurrence of the genus in post Eocene deposits (Cappetta 1980, 2006, 2012). The hexagonal shape of the crown (with angular crown extremities) and the presence of a posterior bulge on the labial face favouring the interlocking, missing in Hypolophodon, suggest that the tooth should be reattributed to Pastinachus. The validity of the species $P$. malembeensis remains challenging because it relies on a unique antero-lateral upper tooth that was formerly distinguished from Hypolophodon sylvestris on the basis of the labial marginal angles that involve more sharped and stronger tooth imbrication (Dartevelle and Casier 1959, p. 331), two features which define the genus Pastinachus, not a new species. Only a better knowledge of this Oligocene material will allow to confirm this attribution. According to Cappetta (2006, 2012), Pastinachus also occurs in the Neogene of Taiwan (formerly as Dasyatis sp., in Uyeno 1978, pl.4, fig. 25A-b), with a unique tooth sampled in the river bed of Ts'ai-liao-hsi, Taiwan. Otherwise, the caudal vertebrae from the Eocene of Etterbeck (Belgium), attributed to Hypolophus sephen by Hasse (1879, pl.XIX, Fig 1,3) are seemingly not belonging to a Pastinachus species. Indeed, the identification based upon only one caudal vertebrae is extremely vague.

\section{NEW FOSSIL PASTINACHUS OF TUNISIA}

The sedimentology, stratigraphy and dating of the KEB-1 fossil-bearing locality were detailed in Marivaux et al. (2014b) and Merzeraud et al. (2016). We only report here the main information from both works devoted to this. Located in central Tunisia, in the Kasserine area (Fig. 2A), the Djebel el Kébar is an anticlinal structure of Atlasic 
direction, which was formed during the Miocene and Lower Pleistocene compressive stages related to the Alpine collision. On the south eastern flank of the djebel, the base of the stratigraphic section (Fig. 2B) was previously described as recording continental deposits. In contrast, the overlying deposits of the section (Fig. 2B-C) are clearly marine in origin, and represent an interval of deposition ranging from the Eocene up to the Miocene. In these marine deposits, two sedimentological units can be identified. The first one is developed above an erosional transgressive surface and is characterized by facies of shallow marine environments, probably formed in subtidal or high intertidal zones (Merzeraud et al. 2016). The proximal facies reflect lagoonal conditions, which were episodically influenced by storms, as indicated by the presence of bioturbated glauconitic clays (Fig. 2C), burrowed limestone pebbles, and carbonated hummocky cross stratifications. In contrast, the distal facies are clearly marked by open marine conditions. The fossil locality (KEB-1; see Marivaux et al. 2014a-b; Merzeraud et al. 2016) having yielded the Pastinachus teeth was discovered in the proximal facies. The great abundance of glauconite grains, notably in the fossiliferous level, indicates episodes of condensation associated with transgressive stages. The fossiliferous concentration of KEB-1, which includes an association of marine (e.g., elasmobranchs) and continental vertebrates (Marivaux et al. 2014a-b) is then associated with several periods of low sedimentation rate of late Middle Eocene. This time frame is corroborated and specified (i.e., Bartonian) by radiometric K-Ar analyses, which were performed on few grains of glauconite extracted from the glauconitic clays embedding the fossils of KEB-1 (see Yans in Marivaux et al. 2014b). About thousand teeth of new taxa were recovered by in situ wet screening of about 2.3 tons of sediments. Figured specimens, including the holotype, are housed in the paleontological collections of the museum of the "Office National des Mines" of Tunis, Tunisia 
Family Dasyatidae Jordan 1888

Subfamily Hypolophinae Stromer 1910

Genus Pastinachus Ruppell 1829

Type-species: Pastinachus sephen

Pastinachus kebarensis nov. sp.

Fig. 3

Diagnosis: fossil species of Pastinachus only known by numerous isolated teeth displaying a large size (up to $6.7 \mathrm{~mm}$ wide) and particularly thick and robust crowns with presence of posterior bulge on labial face (under the labial visor) in lateral teeth. When unworn and unaltered, the occlusal surface of crown of antero-lateral teeth shows a fine and irregularly pitted or alveolate ornamentation of its enameloid. Rhombic to hexagonal in shape, the crown is extremely elongated in the lateral upper teeth (twice broader than long), a peculiar shape reminiscent to that observed in upper teeth of myliobatids and rhinopterids.

Derivation nominis: for the name of the locality (Djebel el Kébar) where the new species was discovered.

Holotype: upper lateral tooth (KEB1-080).

Material: thousand teeth, including the figured teeth (KEB1-076 to KEB1-085).

Type locality: Kébar 1 (KEB-1), southeastern flank of Djebel el Kébar, Amamria hamlet, near Soug-Jedid village (Sidi Bouzid Township), central Tunisia (after Marivaux et al. 2014a-b; Merzeraud et al. 2016). 
Age: Late middle Eocene (Bartonian). Dated at 39.5 Ma by radiometric K-Ar analyses performed on grains of glauconite extracted from the glauconitic clays embedding the fossils of KEB-1 (the ages range from $38.76 \pm 1.0$ to $40.76 \pm 1.1 \mathrm{Ma}$; see Yans in Marivaux et al., 2014b).

Formation: Souar-Fortuna Formations

Description: In Pastinachus, the dentition is monognathic and dignathic heterodont. In occlusal view from symphyseal (Fig. 3 A-E) to commissural tooth files (Fig. 3 AE-AG), teeth vary from rhomboid (near symphysis) to hexagonal (lateral tooth files) on the upper jaw. The monognathic heterodonty is less noticeable on lower jaw, except with the commissural teeth that are, in both jaws, strongly asymmetrical with an angular and rounded side (Fig. 3 AE-AG). The crown is high and primarily composed of osteodentine as in living species. When they are not worn (e.g., in upper symphyseal tooth), crown wears form a sinuous occlusal surface (Fig. 3 A-E) and/or an irregular and alveolate enameloid (Fig. 3 AR-AS). The root type is holaulacorhize, except in some abnormal teeth. It is always narrower than the crown, and does not widen toward the base, except in symphyseal and some anterior upper teeth. Its two lobes are separated by a deep and broad groove where nutritive foramens open. In P. kebarensis nov. sp., the largest tooth observed (from upper lateral tooth file) is $7 \mathrm{~mm}$ large (Fig. $3 \mathrm{U}-\mathrm{Y}$ ). It is almost twice the width of lower lateral teeth (Fig. 3 U-Y), and almost five times the size of upper symphyseal-anterior teeth (Fig. 3 A-J), as observed in fresh material (Fig. 1).

The holotype is a large upper lateral tooth (Fig. $3 \mathrm{U}-\mathrm{Y}$ ). It corresponds to the more elongated tooth (twice broader than long), which was probably located in the middle of the convex upper dental plates (see Fig. 1). Lateral teeth from the upper jaw (Fig. $3 \mathrm{~K}-\mathrm{AD}$ ) are the widest of the mouth. The occlusal surface is flat (because often 
weathered) to rounded (Fig. 3 P-T), and its contour is hexagonal, asymmetrical in the most anterior (Fig. 3 K-O) to virtually symmetrical (Fig. 3 U-Y) in occlusal view. The crown thickness decreases from the mesial to the distal side of the tooth (or inversely, Fig. 3, R-T, AC-AD) on lateral teeth located on both sides of the longest ones (e.g., Holotype). In worn teeth, the crown is sometimes almost totally weathered (Fig. 3 ZAC) but when it is preserved, its occlusal part is always longest than its base (e.g., Fig. $3 \mathrm{~T}, \mathrm{~W}$ ). Except for the first lateral tooth in contact with the last anterior tooth (Fig. 3 K-O), the labial and lingual faces are almost straight and vertically sided (Fig. $3 \mathrm{~S}, \mathrm{Y}$ ), thereby indicating that lateral teeth are closely juxtaposed. The low lingual minute bulge of the lingual face (e.g., Fig 3 T, W) inserts under the neighbour labial visor of following tooth, which is shorted. Roots of lateral teeth are particularly low, largely narrower than the crowns, with symmetrical pentagonal lobes in basal view (Fig. 3 V), while they are asymmetric in first and last lateral tooth files (Fig. 3 N, Q, AA). Lingual marginal foramina are absent on the root and only one or two median nutritive foramina open in the large hollow (Fig. 3 Q, V, AA). The first lateral tooth (Fig. 3 K-O) displays a mixture of characters between the anterior rhombic teeth (e.g., Fig. 3 F-J) and the lateral hexagonal teeth (e.g., Fig. 3 P-Y). These teeth are hexagonal in shape but are characterized by their asymmetry because they articulate with the smallest teeth (anterior tooth) on their mesial side and with the largest lateral tooth on their distal side. In lateral view (Fig. $3 \mathrm{~L}$ ), the labial visor is angular, recalling what we observe in more anterior teeth (e.g., Fig. $3 \mathrm{H}$ ). In occlusal view (Fig. $3 \mathrm{~N}$ ), the mesial lobe of the root is pentagonal (as in more lateral), while the distal lobe is semi-circular (as in anterior teeth). In proportions, the tooth is wider than high as in lateral teeth.

On the rest of the upper jaw, the symphyseal teeth (Fig. 3 A-E), rhombic in shape, are mostly reminiscent of dasyatid tooth pattern. Because they are poorly 
subjected to abrasion, the ornamentation is fairly well preserved (Fig. 3 A), and the occlusal surface appears sometimes strongly hilly. The crown is high and its labial face is strongly concave with a deep median V-shaped furrow between the ornamented flat occlusal surface and the labial rounded labial visor (Fig. 3 C-D). The transverse keel has a lingual tip, which, although broken, is protruding above the lingual face, appearing concave in lateral view (Fig. 3 C). The root is high and bilobed with two diverging lobes separated by a deep axial furrow, as observed in modern Pastinachus representatives (Fig. 1 F). The anterior teeth (Fig. 3 F-J) are quite similar to previous ones with dasyatid design, unlike they are slightly subject to wear. According to their position along the jaw, the wearing of crowns is more or less pronounced and the occlusal surface can be totally flattened and smooth (Fig. 3 G). Root lobes are more robust and less divergent compared to symphyseal teeth. In basal view, the root lobes of symphyseal and anterior teeth are semi-circular (Fig. 3 E, J).

On the lower jaws, symphyseal and antero-lateral teeth (Fig. 1, U-Y) are hexagonal but smaller and less extended labiolingually than in lateral upper teeth. In occlusal view (Fig. 3 AH, AM, AR), the labial extremity of the crowns is always narrower than the lingual one, forming a hexagon somewhat asymmetric. The occlusal surface is slightly convex to flat depending on the degree of wear. Like on the anterior and first lateral teeth of upper jaws, the labial visor of lower teeth is angular, but the slope is steeper. For each tooth, the root is relatively robust and low, with vertical lobes, sub-pentagonal in shape in basal view (Fig. 3 AI, AN).

The posterior tooth files are a succession of strongly asymmetric teeth (e.g., Fig. 1). The mesial side of the crown, articulating with lateral teeth, is angular, while the distal side is round and free (Fig. 3 AE-AG). In lateral view, the crown is anterolaterally elongated (Fig. 3 AG) and very narrow, following a mesio-distal axis. Lingual 
views reveal a thicker crown on the mesial side, was appearing as truncated in its distal side (Fig. 3 AE). The root is oblique and distally oriented. The two lobes, triangular, sub-triangular or sub-pentagonal in shape are elongated as the crown. Their inner outline varies from slightly curved to well linear.

Discussion. Neither ontogenetic nor gynandric heterodonty was observed on the numerous fossil teeth collected. When pristine, the described teeth share an irregularly alveolate ornamentation of the enameloid (Fig. 3 AS), which seems finer than in figured fresh specimen of Herman et al. (1998, fig 10-12) or greater than in figured fresh specimen of Cappetta (2012, fig. 413). However, this is not the case for the upper symphyseal teeth, which can be subject of marked variation. As discussed before, differences between the large upper lateral teeth of $P$. kebarensis nov. sp. (e.g., holotype) and the other fossil species reattributed to Pastinachus (P. ?malembeensis) appear tenuous despite their different age and distinct geographic occurrences. Considering the shape of crown and root lobes (e.g., Fig. 3 U-Y), the unique tooth of $P$. ?malembeensis is undoubtedly a lateral upper tooth. Despite the presence of wear obscuring a possible (or not) enameloid ornamentation, this tooth differs from those of P. kebarensis nov. sp. in having a more massive crown, overhanging larger root lobes. Considering the largest upper lateral tooth of $P$. kebarensis nov. sp. (6.7 $\mathrm{mm}$ in width), the species probably reached a minimum disc wide of $150 \mathrm{~cm}$ by comparison with upper lateral teeth of illustrated fresh specimen jaws, two time smaller than largest living representative (P. ater) with $300 \mathrm{~cm}$ disc wide (Last and Stevens 1994).

\section{GENRAL DISCUSSION AND CONCLUSIONS}


Dental and/or morphological convergences are particularly common within rays, notably across the geological times (e.g., sclerorhynchid/pristid). As remarked by Cappetta (2012, p. 21), some other extant dasyatid (e.g., Dasyatis margarita) and potamotrygonin (e.g., Potamotrygon motoro) species possess such a dental pattern with a strongly arcuate and bulbous upper jaws interlocking with a broad and elongated tooth plate on the lower jaws. However, none have upper lateral teeth with such an elongated and hexagonal crown shape, which strongly recalls what is observed in myliobatid or rhinotpterid tooth plates. Besides, Leriche (1913) grouped fossil myliobatiforms as Rhombodus Dames 1881 and Hypolophytes Stromer 1910, with Pastinachus within the family Hypolophidae on the basis of tooth morphology, which he considered as intermediate between Dasyatidae and Myliobatidae. If all these groups exhibit a similar grinding-type dentition with teeth at the holaulacorhize stage, they are not closely related. The Late Cretaceous rhombodontids and the Paleocene Hypolophytes are also myliobatiforms with grinding-type dentition, but tooth files reveal a slighter monognathic heterodonty and are composed of rhombic or hexagonal and closely juxtaposed teeth, with a high crown marked by a thin wrinkled enameloid. The dental pattern of Pastinachus reminds also that of Pseudohypolophus Cappetta and Case 1975 and Hypolophodon Cappetta 1980. If the first possesses an orthodontin type histology, occurring only in rajiforms, the second displays a tooth pattern with a grinding-type dentition and osteodontin type histology. Even if the elongated teeth of Hypolophodon reminds superficially those of upper lateral teeth of Pastinachus, the crown shape (smoothed polygonal outline), the vascularisation of roots (presence of numerous foramina) and the absence of strong tooth imbrication (lack of posterior bulge) allows clearly distinguishing both genera. The Danian Myliodasyatis Noubhani and Cappetta 1997 also displays a grinding-type dentition with teeth at the holaulacorhize stage that 
might suggest affinities with Pastinachus kebarensis nov. sp. But its small teeth are always broader than long, with crowns showing always hexagonal outlines and the presence of a moderately salient visor, a suite of anatomical details that led original authors to discuss its affiliation to dasyatids (Noubhani and Cappetta 1997; Cappetta 2006). However, these authors suggested that one of the oldest dasyatids from Imin Tanout, Moroccan Meseta (Late Maastrichtian Dasyatis martini Noubhani and Cappetta 1997) have tooth morphology with hexagonal outline, strikingly close to that of the Danian Dasyatis hexagonalis Arambourg 1952, Myliodasyatis or now Bartonian hypolophins. Notwithstanding some different dental features (e.g., lack of well-marked interlocking bulge on labial crown face), D. martini provides a reliable morphological pattern of what we can expect for the dental morphology of the first hypolophins compared to other more recent dasyatids. The minimum divergence estimates from fossil data suggests a splitting event with the other dasyatid subfamilies before 38-40 Myr ago, and possibly before $65 \mathrm{Myr}$ ago if we consider the possible attribution of $D$. martini to hypolophins, which then would strengthen support to the hypothesis that the living Indo-Pacific cowtail stingrays share a plesiomorphic dental morphotype among myliobatiforms when compared with other dasyatids. Such an assumption is surprising but consistent with the molecular and morphological phylogenetic results of Lim et al. (2015), who propose the family Pastinachidae, inasmuch as these approaches failed to classify the species of Pastinachus within a defined monophyletic Dasyatidae clade. Indeed, species of Pastinachidae sensu Lim et al. (2015) have a position that remains in a state of flux, either near the root of myliobatiforms or near the root of some dasyatids (Neotrygonidae sensu Lim et al. 2015). The recent detailed phylogenetic investigations led by Last et al. (2016a), using more marker-rich molecular studies and a more comprehensive taxonomic sampling provide new insights into the generic 
interrelationships of Dasyatidae, considered as monophyletic. Contrary to Lim et al. (2015) who failed to apply for obligatory Zoobank registration of their taxonomic names, Last et al. (2016a) resurrected the subfamily Hypolophinae including the two genera (Pastinachus + Makararaja) and considered that Hypolophin emerges from their phylogenetic analysis as sister clade of all the other subfamilies of Dasyatidae. Whatever the taxonomic issue of debate, hypolophin seems to have a phylogenetic position near the root of clades including whole dasyatids (e.g. Naylor et al. 2012; Lim et al. 2015; Last et al. 2016a). A hypolophin divergence with the other dasyatid subfamilies predating the $\mathrm{K} / \mathrm{T}$ boundary seems in agreement with the more recent phylogenetic relationships and higher-level structure of the Myliobatiformes.

Today restricted to the Indo-pacific area, the cowtail stingrays are very common inshore rays, being sometimes the most common as is the case in Australia (Last and Stevens 1994). Conversely, their known fossil record remains rare and sparse (despite the relative great size of teeth visible on field), likely indicating a distinct special distribution in the past. If Cenozoic batoids and specifically dasyatids are virtually unknown in Southwestern Asia (Adnet et al. 2008, fig. 2, Dasyatis sp.) and Australia (Kemp 1991, Plate 38, Dasyatis sp.), until today the rare record of fossil hypolophins in Indo-pacific indicated that the evolutionary history of cowtail stingrays extended back only to the Miocene, with fossil specimens from Taiwan (Uyeno 1978) and India (Sahni and Mehrortra 1981; Sharma and Patnaik 2013). The Cenozoic dynamics of large-scale batoid diversity remain poorly understood, especially for the Western Pacific, in part, because of the paucity of well-dated fossil records from the tropics. Basically, the fossil record of elasmobranchs from the Western Indian Ocean and Eastern Pacific (originally Tethys) is clearly incomplete, thereby involving a substantial underestimation of the paleodiversity of that group in these areas. In contrast, the Cenozoic record of 
elasmobranchs frequenting the Eastern Indian Ocean area (originally the western part of Neotethys) is better known (e.g., White 1927; Casier 1971; Thomas et al. 1989; Case and West 1991; Kumar and Loyal 1987; Bajpai and Tewissen 2002; Rana et al. 2005; Adnet et al. 2007; Kumar et al. 2007; Andrianavalona et al. 2015). However, no modern hypolophin (e.g. Pastinachus) has been reported from fossiliferous marine/brackish deposits dated from the Early Eocene - Early Oligocene epochs, whereas they are recorded and sometimes abundant in contemporaneous localities along the south coast of the westernmost Neotethys up to the southeastern Atlantic (e.g., Tunisia, Egypt, Southwestern Morocco, and Angola). The lack of hypolophin record in eastern marine areas suggests that cowtail stingrays were really absent, at least from western Indian Ocean before Early Miocene, while they frequented the tropical seawater of North and Western Africa coasts. In this context, Pastinachus kebarensis nov. sp. from the Bartonian of Tunisia represents therefore the oldest members of the group to be know thus far. Based on the known hypolophin fossil record (here updated), it seems that cowtail stingrays performed a rapid and widespread colonization of African coasts flanked by eastern Atlantic and westernmost Neotethys during the warm episodes recorded in the late Paleogene. Cowtail stingrays seems to have survived in southeastern Proto Mediterranean sea until the Early Miocene (Argyriou et al. 2015) after which there is no more record of hypolophin outside the Indo-Pacific area. The distribution area of past hypolophins was therefore more widespread than today.

If the spatial distribution of past and present hypolophins has radically changed, their ecology, inferred from the fossils, seems to have remained unchanged through time. Merzeraud et al. (2016) interpreted the fossil-bearing deposits of Djebel el Kébar (KEB-1) as belonging to very shallow water-depth carbonate platform (wave dominated and influenced by storms and tide), as also suggested by the presence of numerous 
terrestrial mammal remains (see chapter 2). As in Tunisia, fossil teeth of Pastinachus are often recovered elsewhere in Paleogene deposits with forestland mammal bones (e.g., Dartevelle and Casier 1943; Adnet et al. 2010; Murray et al. 2010). With a similar fossil association recorded in the Fayum BQ-2 locality (Egypt, early Late Eocene), Murray et al. (2010) concluded that fossil Pastinachus (formerly Hopolophodon aff. $H$. malembeensis in text) frequented an area representing a near-coastal environment of shallow streams that were often stagnant but flooded periodically, possibly seasonally, with freshwater runoff. Other fossil evidence (e.g. Adnet et al. 2011; Antar 2011 ; Underwood et al. 2011) suggest that coeval Pastinachus representatives inhabited also the marine inshore, and precisely, in shallow and macrotidal environment, interpreted as dune or channel bar sets (Underwood et al. 2011). Nowadays, all Pastinachus species are considered as amphidromous, resting on shallow-water inshore sand flats and frequently venturing far into estuaries and freshwaters. Paleoenvironments of fossil hypolophins suggest that their habitats and behaviours were alike during the Paleogene.

Acknowledgements

The authors are very grateful to Suzanne Jiquel, Anusha Ramdarshan and Anthony Ravel (ISE-M, Montpellier), and Faouzi M'Nasri (ONM, Tunis) for their assistance during the field seasons in the Kassérine and Sidi-Bouzid regions in Tunisia. We are indebted to the inhabitants of the Amamria hamlet (near Soug-Jedid village; Sidi Bouzid Township) for their hospitality and technical help during the fieldwork. We thank Etienne Steurbaut (Royal Belgian Institute of Natural Sciences, Leuven) for his examination of the sediment of the KEB-1 locality in search of nannoplancton. Many thanks to Johan Yans (University of Namur, NaGRIDD, Namur) for the K-Ar dating performed on glauconite grains from the glauconitic clays of the KEB-1 locality. Many thanks to Renaud Lebrun (ISE-M, Montpellier, France), the Montpellier RIO Imaging (MRI) and the LabEx CeMEB for access to the mCT-scanning station Skyscan 1076 (ISE-M, Montpellier, France). This research was supported by the French ANR-ERC PALASIAFRICA Program (ANR-08-JCJC-0017), a grant from the "Conseil Scientifique" (CS) 
of the "Université de Montpellier" (UM), and by the ONM of Tunis (AC-1785, 1234, 295 \& 1049). This is ISE-M publication 2018-0XX.

\section{References}

Adnet S, Antoine P-O, Hassan Baqri SR, Crochet J-Y, Marivaux L, Welcomme J-L., Métais G. 2007. New tropical carcharhinids (chondrichthyes, carcharhiniformes) from the late Eocene-early Oligocene of Balochistan, Pakistan: Paleoenvironmental and paleogeographic implications. J Asian Earth Sc. 30: 303-323.

Adnet S, Cappetta H, Beard KC, Marivaux L, Marandat B, Chaimanee Y, Jaeger J-J, Tun ST, Soe AN. 2008. First myliobatiform teeth (Elasmobranchii, Neoselachii) from the Pondaung Formation (late middle Eocene) of Central Myanmar. Neues Jahrb Geol P-A. 247: 335-340.

Adnet S, Cappetta H, Tabuce R. 2010. A Middle-Late Eocene vertebrate fauna (marine fish and mammals) from southwestern Morocco; preliminary report: age and palaeobiogeographical implications. Geol Mag. 147: 860-870.

Adnet S, Cappetta H, Elnahas S, Strougo A. 2011. A new Priabonian Chondrichthyans assemblage from the Western desert, Egypt: Correlation with the Fayum oasis. J

African Earth Sc. 61: 27-37.

Andrianavalona TH, Ramihangihajason TN, Rasoamiaramanana A, Ward D., Ali JR, Samonds KE. 2015. Miocene Shark and Batoid Fauna from Nosy Makamby (Mahajanga Basin, Northwestern Madagascar). Plos One. 10(6): e0129444.

Antar MS. 2011. Paleo-environments of the exposed Eocene Sediments between Wadi El-Hitan and east Siwa in the Egyptian Western Desert based on their faunal content especially the vertebrates. [PhD Thesis] Zagazig, Egypt. Zagazig University, Faculty of Science, Geology Department. 
Arambourg C. 1952. Les vertébrés fossiles des gisements de phosphates (Maroc-

Algérie-Tunisie). Notes et Mémoires Serv Géol Maroc. 92 : 1-372.

Argyriou T, Cook TD, Muftah AM, Pavlakis P, Boaz NT, Murray AM. 2015. A fish assemblage from an early Miocene horizon from Jabal Zaltan, Libya. J African Earth Sc. 102: 86-101.

Bajpai S, Thewissen JGM. 2002. Vertebrate fauna from Panandhro lignite field (Lower Eocene), District Kachchh, western India. Current Sc. 82: 507-509.

Bonaparte CL. 1832. Iconografia della fauna italica per le quattro classi degli animali vertebrati. Tomo III. Pesci. Roma: Fasc. 1, Puntata 1-6, 2 pls.

Cappetta H, Case GR. 1975. Sélaciens nouveau du Crétacé du Texas. Géobios. 8 : 303307.

Cappetta H. 1980. Modification du statut générique de quelques espèces de Sélaciens Crétacés et Tertiaires. Palaeovertebrata. 10: 29-42.

Cappetta H. 2006. Elasmobranchii Post-Triadici (Index specierum et generum). Leiden: Backhuys Publishers.

Cappetta H. 2012. Chondrichthyes II Mesozoic and Cenozoic Elasmobranchii: Teeth, Handbook of Paleoichthyology. Stuttgart-New York (NY): Verlag Dr Friedrich Pfeil.

Case GR, West RM. 1991. Geology and Paleontology of the Eocene Drazinda Shale Member of the Khirthar Formation, central Western Pakistan, Part II Late Eocene fishes. Tertiary Res. 12: 105-120.

Casier E. 1971. Sur un materiel ichthyologique des "Midra (and Saila) shales" du Qatar (Golfe Persique). Bull Inst R Sc N B-S . 47(2): 1-9

Chaudhuri BL. 1911: Freshwater sting-rays of the Ganges. JAS Bengal. 7: 625-629. 
Dames W. 1881. Über Fischzähne aus der obersenonen Tuffkreide von Maastricht für welcher den Gattungsnamen Rhombodus vorschlug. Sitzungsberichte der Gesellschaft naturforschender Freunde zu Berlin: 1-3

Dartevelle E, Casier E. 1943. Les poissons fossiles du Bas-Congo et des régions voisines. An Mus R Congo Belge. Sér. A, 3, 2 (1): 1-200.

Dartevelle E, Casier E.1959. Les poissons fossiles du Bas-Congo et des régions voisines. Ann Mus R Congo Belge. Sér. A, 3, 2 (3): 257-568.

Forskål P. 1775. Descriptiones animalium, avium, amphibiorum, piscium, insectorum, vermium / quae in itinere orientali observavit Petrus Forskål. Post mortem auctoris edidit Carsten Niebuhr. Adjuncta est materia medica kahirina atque tabula maris Rubri geographica. Post mortem auctoris edidit Carsten Niebuhr. Hauniae. Descriptiones animalium quae in itinere ad Maris Australis terras per annos 17721773 et 1774 suscepto : $1-20+\mathrm{i}-\mathrm{xxxiv}+1-164$.

Hasse C. 1879. Das natürliche System der Elasmobranchier auf Grundlage des Baues und der Entwicklung ihrer Wirbelsäule. Eine morphologische und paläontologische Studie. I. Allgemeiner Theil: 1-76

Herman J, Hovestadt-Euleur M, Hovestadt DC, Stehmann M. 1998. Part B: Batomorphii. $\mathrm{N}^{\circ} 4 \mathrm{a}$. Order Rajiformes -Suborder Myliobatoidei-Superfamily: Dasyatoidea-Family Dasyatidae-Subfamily Dasyatinae-Genera: Amphotistius, Dasyatis, Himantura, Pastinachus, Pteroplatytrygon, Taeniura, Urogymnus and Urolophoides (inc. supraspecific taxa of uncertain status and validity). Superfamily MyliobatoideaFamily Gymnuridae-Genera: Aetoplatea and Gymnura. Superfamily PlesiobatoideaFamily Hexatrygonidae-Genus: Hexatrygon. In Contributions to the Study of the Comparative Morphology of Teeth and Other Relevant Ichthyodorulites in Living Supraspecific Taxa of Chondrichthyan Fishes. Bull Inst R Sc N B-S. 145-197.

Jordan DS. 1888. A manual of the vertebrate animals of the northern United States, including the district north and east of the Ozark mountains, south of the Laurentian 
hills, north of the southern boundary of Virginia, and east of the Missouri river, inclusive of marine species. 5th edition. $\mathrm{i}-\mathrm{iii}+1-375$.

Kemp NR. 1991. Chondrichthyans in the Cretaceous and Tertiary of Australia. Vickers-Rich P, Monaghan JM, Baird RF, Rich TH (Eds.), Vertebrate Paleontology of Australasia, vol. 15. Melbourne, Australia: Monash University Publications Committee, p. 497-568.

Kumar K, Rana RS, Singh H. 2007. Fishes of the Khuiala Formation (early Eocene) of the Jaisalmer Basin, Western Rajasthan, India. Current Sc. 93: 553-559.

Kumar K, Loyal RS. 1987. Eocene Ichthyofauna from the Subathu Formation, Northwestern Himalaya, India. J Pal Soc India. 32: 60-84.

Last PR, Stevens JD. 1994. Sharks and Rays of Australia. CSIRO, Australia: CSIRO Publishing.

Last PR, Manjaji BM, Yearsley GK. 2005. Pastinachus solocirostris sp. nov., a new species of Stingray (Elasmobranchii: Myliobatiformes) from the Indo-Malay Archipelago. Zootaxa. 1040: 1-16.

Last PR, Manjaji-Matsumoto BM. 2010. Description of a new stingray, Pastinachus gracilicaudus sp. nov. (Elasmobranchii: Myliobatiformes), based on material from the Indo-Malay Archipelago. CSIRO Marine and Atmospheric Research Paper. 32: 115128.

Last PR, Fahmi, Naylor GJP. 2010. Pastinachus stellurostris sp. nov., a new stingray (Elasmobranchii: Myliobatiformes) from Indonesian Borneo. CSIRO Marine and Atmospheric Research Paper. 32: 129-140

Last PR, Naylor GJP, Manjaji-Matsumoto BM. 2016a. A revised classification of the family Dasyatidae (Chondrichthyes: Myliobatiformes) based on new morphological and molecular insights. Zootaxa. 4139: 345-368. 
Last PR, De Carvalho MR, Corrigan S, Naylor GJP, Séret B, Yang L. 2016b. The Rays of the World project - an explanation of nomenclatural decisions. In Rays of the World: Supplementary information (Last PR and Yearsley GK, Eds), CSIRO Special Publication. 1-10

Last PR, White WT, De Carvalho MR, Séret B, Stehmann MFW, Naylor GJP. 2016c. Rays of the World. McEachran JD (Edt) Cornell University Press: CSIRO publishing.

Leriche M. 1913. Les poissons paléocènes de Landana (Congo). Les gisements de poissons paléocènes et éocènes de la côte occidentale d'Afrique. Ann Mus Congo Belge. 1: 67-91.

Lim KC, Lim P-E, Chong VC, Loh K-H. 2015. Molecular and Morphological Analyses Reveal Phylogenetic Relationships of Stingrays Focusing on the Family Dasyatidae (Myliobatiformes). Plos One. 10(4): e0120518.

Macleay W. (1883) Contribution to a knowledge of the fishes of New Guinea. No. III. Proc Linn Soc N S W. ser. 1, 7: 585-598

Marivaux L, Essid EM, Marzougui W, Khayati Ammar H, Adnet S, Marandat B, Merzeraud G, Tabuce R, Vianey-Liaud M. 2014. A new and primitive species of Protophiomys (Rodentia, Hystricognathi) from the late middle Eocene of Djebel el Kébar, Central Tunisia. Palaeovertebrata. 38: 1-17.

Marivaux L, Essid EM, Marzougui W, Khayati Ammar H, Adnet S, Marandat B, Merzeraud G, Ramdarshan A, Tabuce R, Vianey-Liaud M, Yans J. 2014. A morphological intermediate between eosimiiform and simiiform primates from the late middle Eocene of Tunisia: Macroevolutionary and paleobiogeographic implications of early anthropoids: An Early Anthropoid Primate from the Eocene of Tunisia. Am J Phys Anthropol. 154: 387-401.

Merzeraud G, Essid EM, Marzougui W, Ammar HK, Adnet S, Marivaux L, Tabuce R, Vianey-Liaud M. 2016. Stratigraphie et sédimentologie des dépôts marins et 
continentaux d'âge éocène moyen à miocène en Tunisie centrale (région du Djebel el Kébar). B Sol Geol Fr. 187: 11-25.

Müller J, Henle FGJ. 1837. Ueber die Gattungen der Plagiostomen. Arch Naturgesch. 3: $394-401$.

Murray AM, Cook TD, Attia YS, Chatrath P, Simons EL. 2010. A freshwater ichthyofauna from the late Eocene Birket Qarun Formation, Fayum, Egypt. J Vertebr Paleontol. 30: 665-680.

Naylor GJP, Caira JN, Jensen K, Rosana KAM, White WT, Last PR. 2012. A DNA sequence-based approach to the identification of shark and ray species and its implications for global elasmobranch diversity and parasitology. B Am Mus Nat Hist. 367: $1-262$.

Noubhani A, Cappetta H. 1997. Les Orectolobiformes, Carcharhiniformes et Myliobatiformes (Elasmobranchii, Neoselachii) des bassins à phosphate du Maroc (Maastrichtien-Lutétien basal). Systématique, biostratigraphie, évolution et dynamique des faunes. Palaeo Ichthyologica. 8: 1-327.

Pickford M. 1986. Première découverte d'une faune terrestre paléogène d'Afrique subsaharienne. Cr Acad Sci II A . 303: 1251-1254.

Rana RS, Kumar K, Singh H, Rose KD. 2005. Lower vertebrates from the Late Palaeocene-Earliest Eocene Akli Formation, Giral Lignite Mine, Barmer Distrinct, western India. Current Sc. 89: 1609-1613.

Randall JE, Hoover JP. 1995. Coastal Fishes of Oman. University of Hawaii Press.

Roberts TR. 2006. Makararaja chindwinensis, a New Genus and Species of Freshwater Dasyatidid Stingray from Upper Myanmar. Nat Hist B Siam Soc. 54 (2): 285-293

Rüppell WPESE. 1828-1830. Atlas zu der Reise im nördlichen Afrika. Fische des Rothen Meers. Frankfurt am Main (Heinrich Ludwig Brönner): 1-141+3 pp., col. Pls. 
1-35. [Part 1 (1828): 1-26, Pls. 1-6; part 2 (1829): 27-94, Pls. 7-24; part 3 (1830): 95141, Pls. 25-35.]

Sahni A, Mehrotra DK. 1981. The Elasmobranch Fauna of Coastal Miocene sediments of Peninsular India. Biological Memoirs. 5: 83-121.

Semeniuk CA, Dill LM. 2006. Anti-predator benefits of mixed-species groups of cowtail stingrays (Pastinachus sephen) and whiprays (Himantura uarnak) at rest.

Ethology. 112: 33-43.

Sharma KM, Patnaik R. 2013. Additional Fossil Batoids (Skates and Rays) from the Miocene Deposits of Baripada Beds, Mayurbhanj District, Orissa, India. Earth Sc India. 6 (4): $160-184$

Stromer E. 1910. Reptilien und Fischreste aus dem marinen Alttertiär von Südtogo (West Africa). M Dtsch Geol Ges. 62 (7): 478-505.

Thomas H, Roger J, Sen S, Bourdillon-de-Grissac C, Al-Sulaimani Z. 1989. Découverte de vertébrés fossiles dans l'Oligocène inférieur du Dhofar (Sultana d'Oman). Cr Acad Sci II A. 22: 101-120.

Underwood CJ, Ward DJ, King C, Antar SM, Zalmout IS, Gingerich PD. 2011. Shark and ray faunas in the Middle and Late Eocene of the Fayum Area, Egypt. P Geologists Assoc. 122: 47-66.

Underwood CJ, Johanson Z, Welten M, Metscher B, Rasch LJ, Fraser GJ, Smith MM. 2015. Development and evolution of dentition pattern and tooth Order in the skates and rays (Batoidea; Chondrichthyes). Plos One. 10(4): e0122553.

Uyeno T. 1978. A preliminary Report on Fossil Fishes from Ts'o-chen, Tainan. Sci Rep Geo Paleo Taiwan Mus. 1: 5-17.

White EI. 1927. Fossil sharks' teeth from the Zanzibar Protectorate. Rep Paleontol Zanzibar Protectorate. 121-123. 
White EI. 1931. The vertebrate faunas of the English Eocene. I. From the Thanet Sands to the Basement Bed of the London Clay. Brit Mus (Nat Hist). 1-121. 
Figure 1. 3D models of both upper and lower jaws of Pastinachus ?ater, male of $75 \mathrm{~cm}$ DW from Java (UM REC 818M). A-B: labial and lingual view of jaws; C-G: views of isolated dental plates with C. occlusal view of both dental plates with tooth files explanation, D. lateral view of both dental plates, E-F: basal views of upper tooth plate; G. labial view of lower tooth plate; H: transversal x-ray scanning of left upper tooth plate. Abbreviations: u.s, upper symphyseal tooth; u.a, upper anterior teeth; u.1, upper lateral teeth; u.p, upper posterior tooth; 1.s, lower symphyseal tooth; 1.al, lower anterolateral teeth; 1.p, lower posterior tooth.

Figure 2. Locality of KEB-1, Djebel el Kébar, Sidi-Bouzid region, Tunisia. A, Simplified map of Tunisia locating the Djebel el Kébar in central Tunisia; B, the pastinachus outline indicates the level having yielded the fossil-bearing KEB-1 locality; $\mathrm{C}$, photograph showing the typical badlands of variegated clays from the early Tertiary sequence of Djebel el Kébar. See Merzeraud et al. (2016) for precise details about geological settings.

Figure 3. Pastinachus kebarensis nov. sp. A-E: upper symphyseal tooth (KEB1-076) in A, occlusal view; B, lingual view; C, profile; D, labial view; E, basal view. F-J: upper anterior tooth (KEB1-077) in F, occlusal view; G, lingual view; H, profile; I, labial view; J, basal view. K-O: first upper lateral tooth (KEB1-078) in K, occlusal view; L, profile; M, lingual view; N, basal view; O, labial view. P-T: upper lateral tooth (KEB1079) in P, occlusal view; $Q$, basal view; R, labial view; S, profile; T, lingual view. U-Y: upper lateral tooth (Holotype KEB1-080) in U, occlusal view; V, basal view; W, lingual view; X, labial view; Y, profile. Z-AD, upper lateral tooth (KEB1-081) in Z, occlusal view; AA, basal view; $\mathrm{AB}$, profile; $\mathrm{AC}$, lingual view; $\mathrm{AD}$, labial view. AE-AG: posterior tooth (KEB1-082) in AE, lingual view; AF, labial view; AG, profile. AH-AL: Lower antero-lateral tooth (KEB1-083) in AH, occlusal view; AI, basal view; AJ, profile; AK, lingual view; AL, labial view. AM-AQ: lower antero-lateral tooth (KEB1084) in AM, occlusal view; AN, basal view; AO, profile; AP, lingual view; AQ, labial view. AR: lower antero-lateral tooth (KEB1-085) in occlusal view with AS, magnificence of occlusal surface of crown. Scale bar $=1 \mathrm{~mm}$ except for AS. 
2

3

4

5

6

7

8

10

11

12

13

14

15

16

17

18

19

20

21

22

23

24

25

27

28

29

30

31

32

33

34

35

36

37

39

40

41

42

43

44

45

46

47

48

49

50

51

52

53

54

55

56

57

58

59

60

URL: http://mc.manuscriptcentral.com/ghbi 


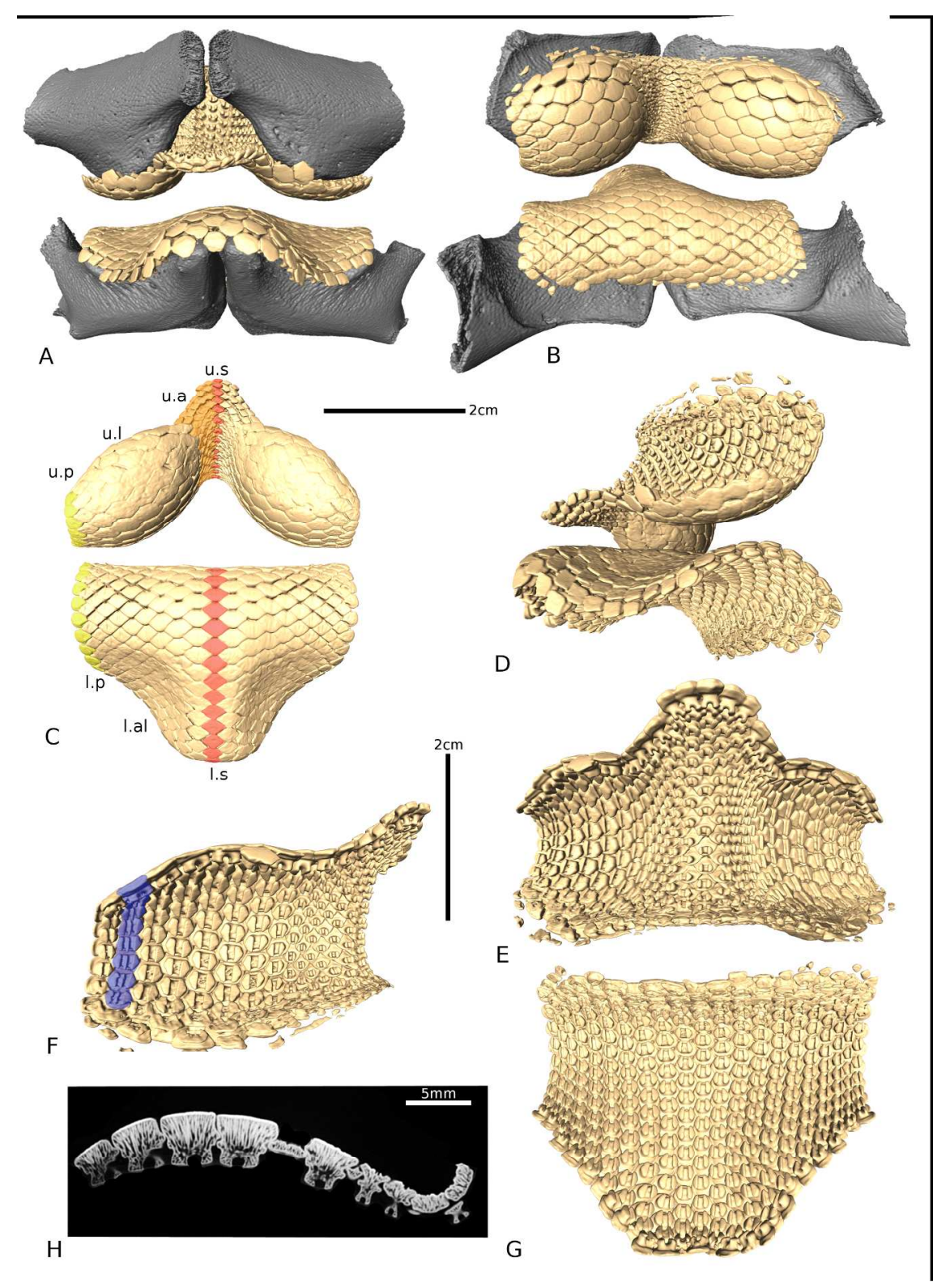

Figure 1. 3D models of both upper and lower jaws of Pastinachus ?ater, male of $75 \mathrm{~cm}$ DW from Java (UM REC 818M). A-B: labial and lingual view of jaws; C-G: views of isolated dental plates with C. occlusal view of both dental plates with tooth files explanation, D. lateral view of both dental plates, E-F: basal views of upper tooth plate; G. labial view of lower tooth plate; $\mathrm{H}$ : transversal $\mathrm{x}$-ray scanning of left upper tooth plate. Abbreviations: u.s, upper symphyseal tooth; u.a, upper anterior teeth; u.l, upper lateral teeth; u.p, upper posterior tooth; I.s, lower symphyseal tooth; I.al, lower antero-lateral teeth; I.p, lower posterior tooth.

$$
289 \times 400 \mathrm{~mm}(300 \times 300 \mathrm{DPI})
$$



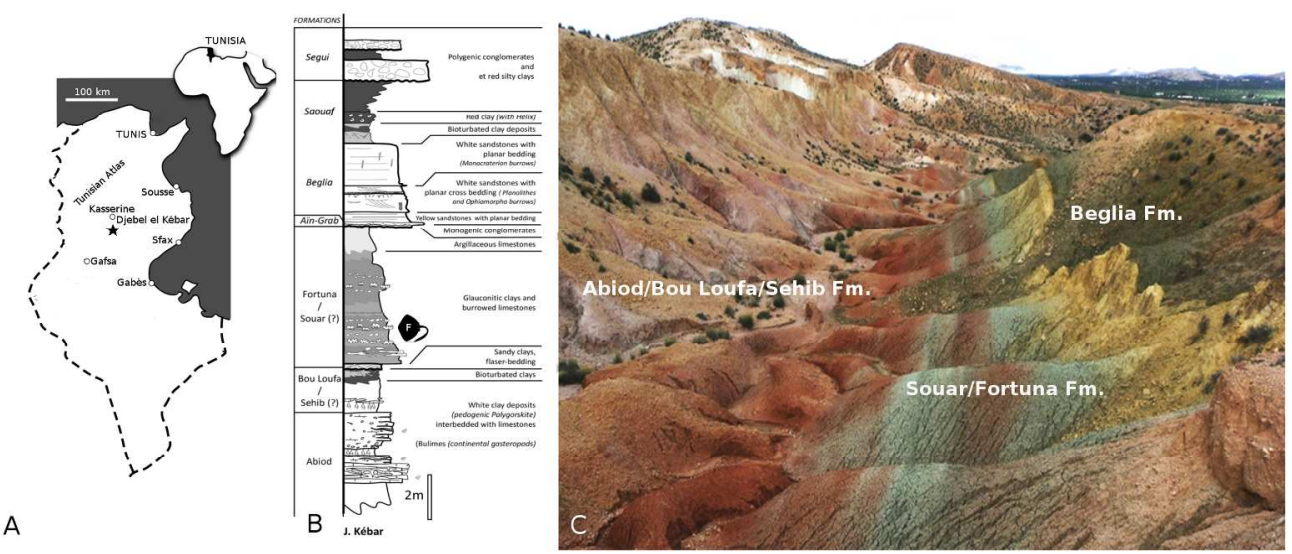

Figure 2. Locality of KEB-1, Djebel el Kébar, Sidi-Bouzid region, Tunisia. A, Simplified map of Tunisia locating the Djebel el Kébar in central Tunisia; B, the pastinachus outline indicates the level having yielded the fossil-bearing KEB-1 locality; C, photograph showing the typical badlands of variegated clays from the early Tertiary sequence of Djebel el Kébar. See Merzeraud et al. (2016) for precise details about geological settings.

$392 \times 172 \mathrm{~mm}(300 \times 300 \mathrm{DPI})$ 


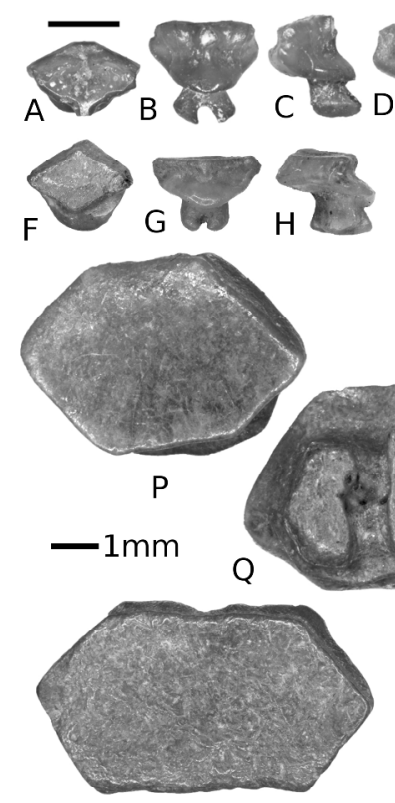

.
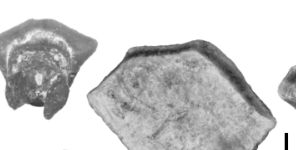

L
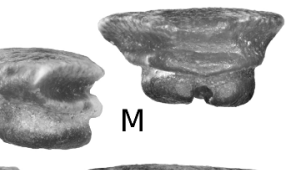

M

U

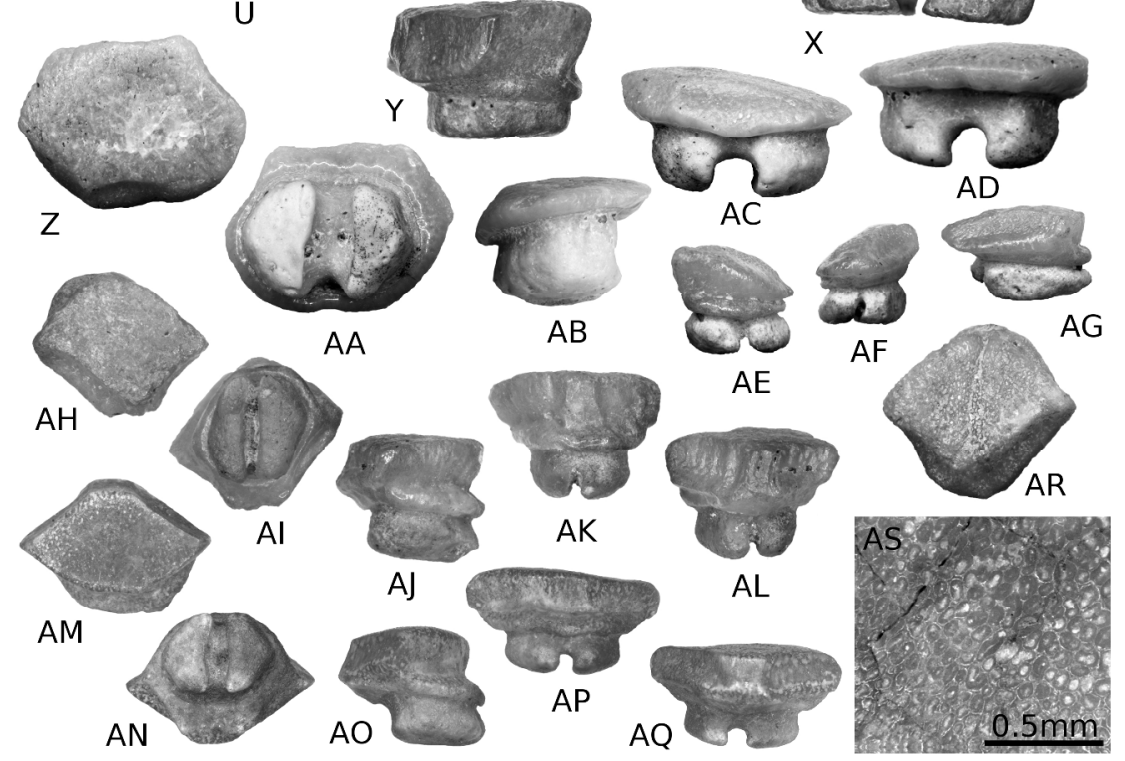

Figure 3. Pastinachus kebarensis nov. sp. A-E: upper symphyseal tooth (KEB1-076) in A, occlusal view; B, lingual view; C, profile; D, labial view; $E$, basal view. F-J: upper anterior tooth (KEB1-077) in F, occlusal view; G, lingual view; H, profile;, I, labial view; J, basal view. K-O: first upper lateral tooth (KEB1-078) in K, occlusal view; L, profile; $M$, lingual view; N, basal view; O, labial view. P-T: upper lateral tooth (KEB1-079)

in $\mathrm{P}$, occlusal view; $\mathrm{Q}$, basal view; $\mathrm{R}$, labial view; $\mathrm{S}$, profile; $\mathrm{T}$, lingual view. U-Y: upper lateral tooth (Holotype KEB1-080) in U, occlusal view; V, basal view; W, lingual view; $X$, labial view; Y, profile. Z-AD, upper lateral tooth (KEB1-081) in Z, occlusal view; $A A$, basal view; $A B$, profile; $A C$, lingual view; $A D$, labial view. $A E-A G$ : posterior tooth (KEB1-082) in $A E$, lingual view; $A F$, labial view; $A G$, profile. AH-AL: Lower antero-lateral tooth (KEB1-083) in $A H$, occlusal view; $A I$, basal view; $A J$, profile; $A K$, lingual view; $A L$, labial view. AM-AQ: lower antero-lateral tooth (KEB1-084) in AM, occlusal view; $A N$, basal view; $A O$, profile; $A P$, lingual view; $A Q$, labial view. AR: lower antero-lateral tooth (KEB1-085) in occlusal view with $A S$, magnificence of occlusal surface of crown. Scale bar $=1 \mathrm{~mm}$ except for AS. 